\title{
An Preliminary Survey of Earthworm Species Composition and Distribution in the north Karnataka region, Gulbarga, Karnataka
}

\author{
Sharanappa Padashetty*, Murali Jadesh \\ Department of Zoology, Gulbarga University, Gulbarga - 585106, Karnataka, India \\ *E-mail address: manjunathk2007@rediffmail.com
}

\begin{abstract}
A preliminary survey on earthworm species from north Karnataka region, Gulbarga district, Karnataka state, India, has been conducted from January 2012 to December 2013. Survey was conducted in three regions of Gulbarga district i.e. Afzalpur, Chittapur, and Sedam taluk. Six species of earthworms were identified belonging to four families namely lumbricidae, Octochaetidae, Megascolecidae and Eudrilidae. Eisenia fetida belonging to family lumbricidae, Dichogaster bolaui belong to family Octochaetidae, Polypheretima elongate, Perionyx sansibaricus and Perionyx excavates belong to family Megascolecidae and Eudrilus eugeniae belonging to family Eudrilidae. Among the species, Eudrilus engeniae does not occur naturally and are produced from external sources for vermicomposting units.
\end{abstract}

Keywords: Earthworms; north Karnataka; Gulbarga

\section{INTRODUCTION}

Earthworms are important soil invertebrates belonging to the Phylum Annelida and Class Oligochaeta. Since long earthworms have been known as "Farmer"s friend", "Nature"s best fertilisers" and "Intestine of earth". Earthworms includes 3 orders, 4 suborders, 7 super families, 27 families and 8 sub families. Earthworms belong to the Order Oligochaeta of the Phylum Annelida. Oligochaetes are bilaterally symmetrical coelomate invertebrates with internal and external metameric segmentation throughout the body. Oligochaetes are often divided into two convenient groups Microdrili and Megadrili. During the last Decade (Ismail, 1997) much Taxnomic work on Indian earthworms has been carried out by Julka (1975) and (Easton, 1982) Identification, taxonomic characters of the earthworms was done through (Julka, 1988). Earthworms are among the most important components of soil biota in terms of soil formation, maintenance of soil structure and fertility (Bhadauria \& Saxena 2010). Although not numerically dominant, their size makes them one of the major contributors to invertebrate biomass in soils (Edwards 2004). Approximately 4,400 different species of earthworms have been identified worldwide (Sinha 2009), with reports on diversity of earthworms in various parts of the world including those of Tsai et al. (2000); Blakemore (2003); Chang \& Chen (2005); Blakemore et al. (2006); Sautter et al. (2006). Julka et al. (2009) reported 590 species of earthworms from India and although earthworms are well 
studied in other parts of India (Chaudhuri et al. 2008; Karmegam \& Daniel 2007; Sathianarayanan \& Khan 2006; Tripathi \& Bhardwaj 2004; Bisht et al. 2003).

Research has shown that earthworm species composition and distribution is dependent upon the properties of the soil, including soil moisture, texture, depth, $\mathrm{pH}$, and organic matter content (Curry 2004). However, local earthworm distribution can also significantly affect soil structure, varies from species to species.

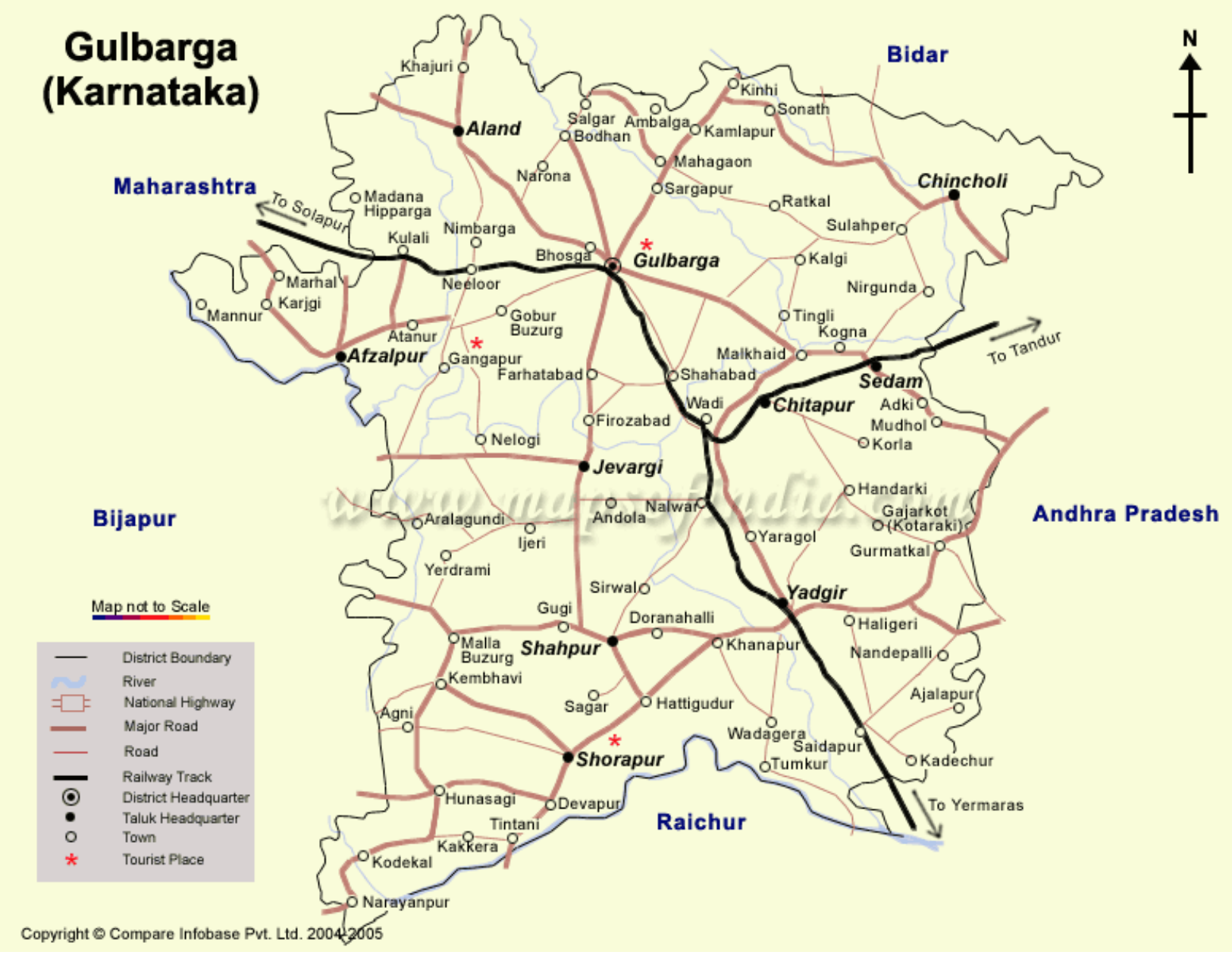

Figure 1. Study area.

The most important aspect of earthworm ecology is their feeding activity. Earthworms gain nutrition from the soil or leaf litter they ingest, extracting the organic matter, which includes root and leaf litter debris, and grinding it in their gizzard (Curry 1998). The waste they expel forms structures called casts. Their feeding and cast forming characteristics significantly affect soil structure significantly (Edwards and Shiptalo 1998). As a result of their feeding and burrowing activity, earthworms (particularly endogeic and anecic worms) thoroughly mix organic and mineral components of the soil (Edwards and Shiptalo 1998). Such activity can reduce forest floor thickness, which is considered to be a key component of the inherent stability of many forest ecosystems (Bohlen et al. 2004, Hale et al. 2005). Earthworm burrows affect the porosity (permeability to fluids) of soil. The extent to which 
soil porosity is affected depends largely on the number of earthworms in the soil, their spatial distribution, and their size. Increased soil porosity reduces soil erosion and may increase percolation through the soil profile. A recent study determined that earthworms alter carbon: nitrogen ratios, phosphorus fractions, and the distribution and function of fine roots and microbes (Doube and Brown 1998). While these effects may be beneficial to agricultural systems, they may be harmful to forest ecosystems over long periods of time if the forest is composed of plant species which have evolved or succeeded in the absence of earthworms (Bohlen et al. 2002, Hendrix and Bohlen 2002).

The present study is to investigate the distribution of the earthworms in the north Karnataka region correlating their distribution to physic-chemical factors of soils they inhabit.

\section{MATERIALS AND METHODS}

The Study area includes three regions of Gulbarga district i.e. Afzalpur,Chittapur and Sedam taluk. Survey was conducted in the study area from January 2012 to December 2013. Gulbarga district is located on the North-Eastern part of Karnataka. Geographically it lies between $17^{\circ} 04^{\prime}-77^{\circ} 42^{\prime}$ longitude and $16^{\circ} 12^{\prime}$ - $17^{\circ} 46^{\prime}$ latitude and placed 45 meters above the mean sea level. Gulbarga possesses a typical climate of South Indian pennisula with semi-arid conditions, with temperature between $14-45^{\circ} \mathrm{C}$ in winter to in summer and the average rainfall being $702 \mathrm{~mm}$ (Figure 1).

\section{EARTHWORM SAMPLING}

Earthworms for the present taxonomic study were collected by digging and hand sorting method. Samples were taken from three study area, Afzalpur, Chittapur and Sedam taluk (http://www.homatherapyindia.com/sites/gulbarga.GIF. 2013)

Habitat such as coconut plantation, vegetable garden, areca plantation, banana plantation, flowering gardens and few lentic and lotic water bodies have been selected for earthworm species collection. Sampling were done in triplicate using the quantitative modified hand sorting standard methods of surface $30 \times 30 \mathrm{~cm}$ area.

Later, soil was excavated up to $30 \mathrm{~cm}$ depth in each sampling point and available earthworms were collected. Specimens were fixed in 30\% alcohol for about 2 minutes for anesthetizing and then transferred to $10 \%$ formalin solution for permanent preservation. Earthworms were dissected out immediately after alcohol treatment to study the internal anatomical features for identification.

The specimens were deposited in the department museum. Earthworms were identified with the help of monographs and other available literature on the subject (J.M. Julka, 1988). For statistical analysis six samples from each study area were taken and the statistical calculations such as arithmetic mean, standard deviation and standard error were made as described by Snedecor (1946).

Soil samples collected from various study sites were analyzed for soil texture by international Pipette method (Piper, 1966), moisture by oven drying method (Santhanam et al., 1989), pH by Digital meter (Mishra, 1968). Percentage of organic carbon (OC \%), Phosphorus (P) kg/acre, Potash (K) kg/acre were measured in the Agriculture Soil Testing Centre, Gulbarga. 


\section{DISCUSSION AND CONCLUSIONS}

A total of six species of Earthworms have been recorded from the study area. Six species of earthworms were identified belonging to four families namely lumbricidae, Octochaetidae, Megascolecidae and Eudrilidae. Eisenia fetida belonging to family lumbricidae, Dichogaster bolaui belong to family Octochaetidae, Polypheretima elongate, Perionyx sansibaricus and Perionyx excavates belong to family Megascolecidae and Eudrilus eugeniae belonging to family Eudrilidae (Table 1).

Table 1. Checklist of earthworm in north Karnataka region, Gulbarga (Afzalpur, Chittapur, Sedam).

\begin{tabular}{|c|c|c|}
\hline S.NO & Family & Species \\
\hline 1 & Lumbricidae & Eisenia fetida \\
\hline 2 & Octochaetidae & Dichogaster bolaui \\
\hline 3 & Megascolecidae & Perionyx excavatus \\
\hline & & Perionyx sansibaricus \\
\hline 4 & & Polypheretima elongata \\
\hline
\end{tabular}

Among the species, Eudrilus eugeniae does not occur naturally and are produced from external sources for vermicomposting units.

The study showed that the family Megascolecidae was dominant in all the habitats of the study area. This study also showed that the species Polypheretima elongate size ranges from 9.5 to $230 \mathrm{~mm}$ and Dichogaster bolaui is the smallest in the length, size ranges from 25 to $40 \mathrm{~mm}$ in length.

Results of the soil analysis show, the $\mathrm{pH}$ ranges from $6.8 \pm 0.11$ to $7.0 \pm 0.13$. Salts content varies from $0.29 \pm 0.04$ to $0.85 \pm 0.11$. OC ranged from $0.33 \pm 0.04$ to $0.60 \pm 0.02$. P $\mathrm{kg}$ /acre ranges between $12 \pm 1.02$ to $12.90 \pm 0.6$. $\mathrm{K} \mathrm{kg}$ /acre varies from $200.9 \pm 20.60$ to 220.0 \pm 41.16 . Moisture content ranges from $67.9 \%$ to $82.8 \%$ (Table 2 ).

In recent years, the diversity of Indian earthworms has been mainly studied by Julka (1988). He described the family Octochaetidae in the publication 'Fauna of India' providing illustrated descriptions of 154 taxa including 6 new genera and 16 species. The knowledge on the earthworm fauna of India has also been enriched by Julka and Senapati (1987), Senapati et al. (1990), Julka and Paliwal (1994) and Paliwal and Julka (2005).

The present study reveals more or less similar findings of other researchers in different localities. Present work, therefore, is an attempt in this direction and contributes to update our contemporary knowledge on the biodiversity of earthworms' resources in the study area. 
Table 2. Physicochemical factors of soil of earthworm habitats.

\begin{tabular}{|c|c|c|c|}
\hline Parameters & \multicolumn{3}{|c|}{ Habitat of earthworms } \\
\hline Soil factors & Afzalpur & Chittapur & Sedam \\
\hline pH & $6.8 \pm 0.11$ & $6.85 \pm 0.11$ & $7.0 \pm 0.13$ \\
\hline Salt & $0.29 \pm 0.04$ & $0.29 \pm 0.11$ & $0.85 \pm 0.11$ \\
\hline OC \% & $0.33 \pm 0.04$ & $0.33 \pm 0.07$ & $0.60 \pm 0.02$ \\
\hline P kg/acre phosphorus & $12 \pm 1.02$ & $12.16 \pm 1.11$ & $12.90 \pm 0.6$ \\
\hline K kg/acre potash & $200 \pm 14.30$ & $220.0 \pm 41.16$ & $200.9 \pm 20.60$ \\
\hline $\begin{array}{c}\text { Moisture content of } \\
\text { the soil }\end{array}$ & $73.2 \%$ & $82.8 \%$ & $67.9 \%$ \\
\hline
\end{tabular}

$\mathrm{M} \pm \mathrm{SE}=$ mean \pm standard error.

\section{Reference}

[1] Bhadauria, T. \& K. P. Saxena. 2010. Role of earthworms in soil fertility maintenance through the production of biogenic structures. Applied and Environmental Soil Science 2010: 7pages, doi:10.1155/2010/816073.

[2] Bisht, R., H. Pandey, D. Bharti \& B. R. Kaushal. 2003. Population dynamics of earthworms (Oligochaeta) in cultivated soil of central Himalayan tarai region. Tropical Ecology 44: 221-226.

[3] Blakemore, R. J. 2003. Japanese earthworms (Annelida: Oligochaeta): a review and checklist of species. Organisms, Diversity \& Evolution 11: 1-43.

[4] Blakemore, R. J., Chih-Han Chang, Shu-Chun Chuang, T. Masamichi Ito, Sam James \& Jiun-Hong Chen. 2006. Biodiversity of earthworms in Taiwan: a species checklist with the confirmation and new records of the exotic lumbricids Eisenia fetida and Eiseniella tetraedra. Taiwania 51: 226-236.

[5] Bohlen P.J., P.M. Groffman, T.J. Fahey, M.C. Fisk, E. Suarez, D.M. Pelletier, and R.T. Fahey. 2002. Ecosystem consequences of exotic earthworm invasion of north temperate forests. Ecosystems 7: 112.

[6] Chang, C. H. \& J. H. Chen. 2005. Taxonomic status and intraspecific phylogeography of two sibling species of Metaphire (Oligochaeta: Megascolecidae) in Taiwan. Pedobiologia 49: 591-600.

[7] Chaudhuri, P. S., S. Nath \& R. Paliwal. 2008. Earthworm population of rubber plantations (Hevea brasiliensis) in Tripura, India. Tropical Ecology 49: 225-234.

[8] Curry J.P. 1998. Factors Affecting Earthworm Abundance in Soils. In Earthworm Ecology. Eds C.A. Edwards. CRC Press LLC, Boca Raton, Florida

[9] Doube B.M. and G.G. Brown. 1998. Life in a Complex Community: Functional Interactions Between Earthworms, Organic Matter, Microorganisms, and Plants. In Earthworm Ecology. Eds C.A. Edwards. CRC Press LLC, Boca Raton, Florida. 
[10] Easton, E. G. (1982). The identity of Perichaeta lawsoni Bourne, 1986. (Syn. Megascolex curgensis Michaelsen, 1921) (Megascolecidae: Oligochaeta). Megadrilogica 4(1): 1-3.

[11] Edwards W.M. and M.J. Shipitalo. 1998. Consequences of Earthworms in Agricultural Soils: Aggregation and Porosity. In Earthworm Ecology. Eds C.A. Edwards. CRC Press LLC, Boca Raton, Florida.

[12] Edwards, C. A. 2004. Earthworm Ecology. 2nd edn. St.Lucie Press, Boca Raton.

[13] Hale C.M., P.B. Reich, and L.E. Frelich. 2005. Exotic Earthworm Invasion Dynamics in Northern Hardwood Forests of Minnesota, USA. Ecological Application 15: 848860.

[14] Hendrix P.F. and P.J. Bohlen. 2002. Exotic Earthworm Invasions in North America: Ecological and Policy Implications. Bioscience 52: 801811.

[15] http://www.homatherapyindia.com/sites/default/files/gulbarga.GIF accessed 2013

[16] Ismail, S.A. (1997). Vermicology.The Biology of Earthworms. Orient Longman Ltd., India., $92 \mathrm{pp}$.

[17] Julka JM, Paliwal R (1994). On a new species of Plutellus Perrier (Acanthodrilidae: Oligochaeta from Northwest Himalayas, India, Indian. Res. Bull. Punjab Univ. 44: 217-220.

[18] Julka JM, Senapati BK (1987). Records of the Zoological Survey of India. Miscellaneous Publication. Occ. Pap. 92 Grafic Printall, Calcutta, India pp. 1-105

[19] Julka, J. M., R. Paliwal \& P. Kathireswari. 2009. Biodiversity of Indian earthworms - an overview. pp. 36-56. In: C. A. Edwards, R. Jayaraaj \& I. A. Jayraaj (eds.) Proceedings of Indo-US Workshop on Vermitechnology in Human Welfare. Rohini Achagam, Coimbatore.

[20] Julka, J.M. (1988). Fauna of India: Megadrile Oligochaeta (earthworms). Haplotaxida: Lumbricina; Megadcolecidae; Octochaetidae, Zoological Survey of India, Culcutta, $400 \mathrm{pp}$.

[21] Julka, J.M. 1975. Notes on the earthworms from Darjeeling district, with descriptions of the two new species. Mitt. Zoological Museum Berlin, 51: 19-27.

[22] Karmegam, N. \& T. Daniel. 2007. Effect of physicochemical parameters on earthworm abundance: A quantitative approach. Journal of Applied Sciences Research 3: $1369-1376$.

[23] Misra R (1968). Ecology work book. Oxford and IBH publishing company, Calcutta. India

[24] Paliwal R, Julka JM (2005). Checklist of earthworms of Western Himalaya, India. Zoos Print J. 20(9): 1972-1976.

[25] Piper CS (1966). Soil and Plant Analysis. Hans Publishers, Bombay p. 368.

[26] Santhanam R, Velaycitham P, Jegatheesam (1989). A manual of Fresh water Ecology. Daya Publishing House, Delhi p. 134

[27] Sathianarayanan, A. \& Anisa B. Khan. 2006. Diversity, distribution and abundance of earthworms in Pondicherry region. Tropical Ecology 47: 139-144. 
[28] Sathianarayananan, A. and Anisa, B. Khan, 2006. Diversity, distribution and abundance of earthworms in Pondicherry region. Tropical ecology, 47(1): 139-144.

[29] Sautter, K. D., G. G. Brown, S. W. James, A. Pasini, D. H. Nunes \& N. P. Benito. 2006. Present knowledge on earthworm biodiversity in the State of Parana, Brazil. European Journal of Soil Biology 42: 296-300.

[30] Senapati BK, Julka JM, Dash MC (1990). On a new species of Lennogoster Gates (Octochaetidae: Oligochaeta) from India. Rev. Ecol. Biol. Soil 27: 467-470.

[31] Sinha, R. K. 2009. Earthworms: the miracle of nature (Charles Darwin's'unheralded soldiers of mankind \& farmer's friends'). Environmentalist 29:339-340.

[32] Tripathi, G. \& P. Bhardwaj. 2004. Earthworm diversity and habitat preferences in arid regions of Rajasthan. Zoo's Print Journal 19: 1515-1519.

[33] Tsai, C. F., H. P. Shen \& S. C. Tsai. 2000. Native and exotic species of terrestrial earthworms (Oligochaeta) in Taiwan with reference to northeast Asia. Zoological Sciences 39: 28594. 